\title{
FASILITAS KEGIATAN INTERAKTIF WARGA SEMANAN
}

\author{
Inez Tjahyana ${ }^{1)}$, Rudy Surya ${ }^{21}$ \\ 1)Program Studi S1 Arsitektur, Fakultas Teknik, Universitas Tarumanagara, inez.tjahyana@yahoo.com \\ 2) Program Studi S1 Arsitektur/ S1 PWK, Fakultas Teknik, Universitas Tarumanagara, rs88seb@gmail.com
}

Masuk: 13-07-2020, revisi: 31-07-2020, diterima untuk diterbitkan: 24-09-2020

\begin{abstract}
Abstrak
Fasilitas Kegiatan Interaktif Warga Semanan merupakan sebuah third place yang dibuat dengan latar belakang mengangkat karakteristik dan keseharian warga sebagai inspirasi dari program proyek ini. Mata pencaharian warga yang kebanyakan belum menentu, bahkan banyak yang tidak bekerja, padahal kawasan memiliki potensi sosial ekonomi sebagai kawasan Sentra Flora Fauna dan Perkampungan Tempe, banyaknya pabrik-pabrik dengan pekerja yang tinggal disekitar kawasan Semanan, dengan tingkat stress yang tinggi menjadi salah satu hal yang perlu diperhatikan. Visi dari proyek adalah meningkatkan keterampilan, kemampuan dan kreatifitas serta produktifitas warga. Program yang ditawarkan didalam proyek adalah edukasi, entertainment dan interaksi. Metode yang digunakan dalam penulisan adalah diskriptif, eksplanatoris dan kuantitatif dengan memanfaatkan pengumpulan data primer dan sekunder terhadap kawasan terpilih. Dari hasil pengumpulan data dan literatur dilakukan analisis yang menghasilkan konsep desain dan program dari proyek third place. Dari seluruh proses maka didapatkanlah wadah third place yang dibutuhkan oleh warga yaitu Fasilitas Kegiatan Interaktif Warga Semanan.
\end{abstract}

Kata kunci: program; Semanan; third place

\begin{abstract}
Semanan Interactive Space Facility is the third place created with a background to improve the characteristics and daily lives of citizens as an inspiration for this project program. The livelihoods of the majority of the population are uncertain, many do not even work, while the area has socioeconomic potential such as the Flora Fauna Center and Tempe Village, many factories with workers living around the Semanan area, with high levels of stress being one of the most important needs to be concerned about. The vision of this project is to improve the skills, abilities and creativity and productivity of citizens. The programs offered in this project are education, entertainment and interaction. The method used in writing is descriptive, explanatory and quantitative by utilizing primary and secondary data collection in the selected area. From the results of data collection and literature, an analysis is carried out which results in the design concept and third place project program. From the whole process, a third place that needed by the residents, is Semanan Interactive Space Facility.
\end{abstract}

Keywords: programs; Semanan; third place

\section{PENDAHULUAN} Latar Belakang

Semanan adalah kelurahan yang terletak di kecamatan Kalideres, Jakarta Barat, Daerah Khusus Ibukota Jakarta, Indonesia. Menjadi salah satu daerah yang minim akan fasilitas publik yang dapat dijadikan sebagai ruang interaksi antar warga atau dengan warga lain. Kepentingan bersosialisasi warga menjadi terkesampingkan karena tekanan ekonomi yang menyebabkan warga lebih berfokus untuk mendirikan usaha-usaha rumahan mereka. Dengan pertimbangan berbagai teori dan isu-isu yang ada, proyek third place akan dirancang berangkat dari kawasan sebagai persoalan utamanya. Third place sebagai fasilitas yang dapat dimanfaatkan warga 
sebagai wadah berinteraksi dan menghilangkan penat. Pembuatan third place di kelurahan Semanan dengan program yang sesuai menjadi penting dengan rancangan yang menonjolkan karakter dari masyarakat Semanan, dimana nantinya third place tersebut dapat menjadi wadah yang ideal bagi masyarakat Semanan untuk saling bersosialisasi dan berinteraksi dengan sesamanya dengan leluasa, yang nantinya akan meningkatkan kualitas hidup dari masyarakat dan penggunanya.

\section{Rumusan Permasalahan}

a. Masalah penting apa yang akan terjawab dengan membangun pusat interatif warga Semanan

b. Dalam bentuk dan program yang bagaimana pusat interaktif tersebut akan menjadi maksimal hasilnya

c. Bagaimana bentuk pusat interaktif tersebut sehingga dapat menyatu dengan kepentingan lingkungannya?

\section{Tujuan}

Tujuan dari proyek yang diusungkan adalah untuk memberikan fasilitas publik berupa third place untuk masyarakat saling bersosialisasi dan berinteraksi dengan sesama agar setiap user menjadi pribadi yang lebih humanis, produktif, terbuka, dinamis, dan kreatif. Dimana konsep utama dari third place yang dibuat adalah untuk semakin menonjolkan karakter dari kelurahan Semanan, dan semakin memaksimalkan potensi masyarakat dengan kegiatan dan program bangunan yang playful dan cheerful. Proyek diharapkan dapat memiliki manfaat yang berguna bagi masyarakat kelurahan Semanan yaitu dapat meningkatkan produktivitas masyarakat pada saat berada di 2 nd place mereka masing-masing dengan menghilangkan penat dan menambah kreaktifitas dan kemampuan di program yang diusulkan oleh projek third place.

\section{Ruang Lingkup}

Ruang lingkup dalam penulisan berfungsi sebagai penentuan batasan fokus pada tema dan permasalahan yang diangkat. Maka ditentukan ruang lingkup sebagai berikut, ruang lingkup pembahasan akan membahas tentang kawasan kelurahan Semanan, Kalidereres, dimana subyek pengamatannya adalah kebiasaan, aktivitas warga dan pengunjung Semanan, dan kelurahan Semanan itu sendiri untuk mengetahui kebutuhan warga dalam penentuan program third place.

\section{KAJIAN LITERATUR}

\section{Ray Oldenburg "The Great,Good,Place"}

Ray Oldenburg dalam bukunya yang berjudul "The Great Good Place" mengatakan bahwa The Third Place merupakan tempat ketiga yang dibutuhkan oleh masyarakat selain First Place (Tempat Tinggal) dan Second Place (Tempat Kerja). Dalam bukunya, The Great Good Place, Ray Oldenburg (1999) menyatakan A generic designation for a great variety of public places that host the regular, voluntary, informal and happily anticipated gatherings of individuals beyond the realms of home and work. Menurut Oldenburg ada tiga setting kehidupan yang harus ada untuk memenuhi kebutuhan manusia akan place yaitu rumah sebagai first place, tempat bekerja sebagai second place, dan tempat bersosialisasi dimana orang dapat berkunjung untuk berkumpul sebagai third place. Third place menurut Oldenrburg (1999) adalah tempat untuk orang mengobati stress, kesepian dan keterasingan, third place merupakan suatu tempat yang dijadikan tempat pelarian diri dari first place dan second place untuk membuka jati dirinya dan bertujuan untuk bersosialisasi di dalamnya. Berdasarkan penelitiannya, Oldenburg (1999) mengungkap delapan karakter yang membentuk third place, yaitu: 


\section{a. On Neutral Ground}

Tempat yang bisa dikunjungi oleh setiap individu untuk dapat bebas datang dan pergi walaupun merupakan tempat publik, dimana tempat publik tersebut dapat terasa nyaman bagi setiap individu dengan memberikan tempat yang bersifat netral.

b. Leveler

Tempat yang mempromosikan inklusifitas yaitu bisa menerima berbagai orang tanpa memperhatikan kedudukan atau status dari seseorang, dimana ketika seseorang berada di tempat tersebut kedudukannya menjadi sejajar.

c. Conversation is The Main Activity

Tempat dimana kegiatan utamanya adalah saling bersosialisasi, berkomunikasi. Dimana di dalam tempat ini harus terjadi pertukaran informasi dengan saling berinteraksi.

d. Accessibility and Accommodation

Sebuah third place harus nyaman bagi pengunjung sehingga sebuah third place harus mudah dicapai, yang biasanya merupakan walking distance dari wilayah pelayanannya.

e. The Regulars

Sebuah third place dibuat hidup dengan adanya pengunjung tetap, sehingga tempat tersebut harus bersifat sesuatu yang umum, mengundang.

f. Low Profile

Third Place harus terlihat sebagai bangunan yang tidak berusaha menonjol namun menyelaraskan dengan kekontekstualan sekitar (physically plain and unpretentious).

g. The Mood is Playful

Mood yang dominan dari sebuah third place adalah playful, dimana diharapkan semua pengunjung berada di dalam third place dapat melepas penat, merasa nyaman dan membangkitkan mood pengunjung.

h. A Home Away From Home

Third Place berbeda dengan First Place namun dari segi kenyamanan, sebuah Third place harus memiliki kenyamanan yang mirip dengan first place.

Oldenburg menetapkan tranportasi publik sebagai contoh terbaik dari third place, menurutnya life without community has produced, for many, a lifestyle consisting mainly of a home-towork-and-back-again shuttle. Social well-being and psychological health depend upon community (Oldenburg 1997, p. 7) yaitu kehidupan tanpa komunitas telah menghasilkan sesuatu bagi banyak orang, yaitu gaya hidup yang sebagian besar terdiri dari antar-jemput pulang-kerja-dan-kembali, maka sebuah third place sangat dibutuhkan agar manusia dapat terlepas dari siklus kehidupan tanpa sosialisasi. Dari teori Ray Oldenburg tentang The Third place dapat disimpulkan bahwa untuk membentuk suatu third place yang ideal dibutuhkan kedelapan karakeristik yang nantinya akan menciptakan sebuah third place yang dapat digunakan pengunjungnya sepenuhnya untuk saling berinteraksi dan melepas penat.

\section{Interaktif}

Interaktif berasal dari kata interaktif, yang memiliki arti hal saling melakukan aksi, berhubungan. Interaksi sendiri terjadi karena adanya dua pihak yang saling berhubungan dengan adanya aksi dan reaksi. Definisi dari interaktif menurut KBBI adalah bersifat saling melakukan aksi, antar-hubungan, saling aktif. Dari definisi tersebut dapat disimpulkan kegiatan interaktif merupakan kegiatan yang dilakukan antar dua pihak yang menghasilkan aksi dan reaksi dari kegiatan tersebut.

\section{Kreatifitas}

Third place yang dirancang diharapkan dapat meningkatkan kualitas hidup masyarakat dari segi sosial maupun ekonomi, dengan peningkatan kualitas hidup dibutuhkan kreatifitas seseorang untuk dapat mewujudkan hal tersebut, maka teori kreatifitas dibutuhkan sehingga 
program yang dirancang tepat sasaran dan efektif untuk meningkatkan kreatifitas seseorang. James J Gallagher (1985) mengatakan bahwa "Creativity is a mental process by which an individual creates new ideas or products, or recombines existing ideas and product, in fashion that is novel to him or her" yaitu yang diartikan kreativitas merupakan suatu proses mental yang dilakukan individu berupa gagasan ataupun produk baru, atau mengombinasikan antara keduanya yang pada akhirnya akan melekat pada dirinya. (Kurniati \& Rachmawati, 2010: 13).

Menurut buku karya Richard Florida "The Rise Of The Creative Class, Revisited" dimana buku ini menjelaskan tentang kelas social baru yaitu Creative Class. Menurut Florida, kelas Creative Class inilah yang mendorong pertumbuhan ekonomi, dimana kreatifitas merupakan kuncinya. Meskipun teknologi yang sudah maju semakin berperan dalam meningkatkan pertumbuhan ekonomi suatu perusahaan, namun kreatifitas manusia yaitu pegawainya juga merupakan salah satu faktor yang penting. Kreatifitas manusia tidak muncul begitu saja tanpa adanya wadah untuk mengasah dan memunculkan kreatifitas tersebut, maka "tempat" inilah yang menjadi penting dan esensial. Tempat ini harus dapat melepaskan dan menghilangkan stress seseorang karena stress merupakan salah satu penghambat dari munculnya kreatifitas seseorang, seperti yang dikatakan Adrian Furnman, Ph.D dalam artikel Psychology Today, penting untuk memberikan break terhadap pikiran ketika sudah bekerja aktif dalam beberapa waktu, dimana break tersebut akan melepas stress. Tempat ini juga harus menambah stimulasi kreatif, dimana ketika orang-orang kreatif berkumpul tingkat produktifitas, opportunities dan tingkat kehidupan yang lebih baik. Tempat ini dibutuhkan oleh orang dimana merupakan tempat netral dimana orang dapat datang tanpa harus memperdulikan status mereka, tempat ini harus dapat dijadikan sebagai tempat pelarian stress dan tempat yang dapat membentuk komunitas yang nantinya akan membantu masing-masing individu.

Sebagai kesimpulan dari teori Florida, kreatifitas merupakan salah satu sumber dari pertumbuhan ekonomi, dimana kreatifitas tersebut datang dari manusia, dan kreatifitas tersebut harus dikembangkan dan diasah dengan suatu "tempat", sehingga "tempat" menjadi hal yang esensial untuk mengembangkan kreatifitas tersebut. Sebuah wadah yang bertujuan mengembangkan kreatifitas seseorang juga harus memiliki faktor terpenting untuk mengembangkan kreatifitas yaitu rangsangan baik melihat, mendengar dan bergerak dimana saat seseorang mendapat rangsangan untuk bertindak kreatif maka tingkat kreatifitasnya akan semakin meningkat. Maka dari itu, sebuah wadah yang dapat mengembangkan kreatifitas seseorang menjadi penting untuk pertumbuhan ekonomi Kawasan, dan menjadi tempat yang dapat melepas stress seseorang dimana sebagai hakikatnya tempat yang dapat mengembangkan kreatifitas seseorang harus dapat menjadi tempat yang dapat membantu melepas stress seseorang dan tempat yang memiliki rangsangan untuk pengunjung bertindak kreatif.

\section{METODE}

Langkah dalam proses penelitian dimulai dari pemilihan kawasan. Dipilihlah kawasan Semanan, Kalideres, Jakarta Barat sebagai kecamatan yang tepat. Tahap kedua dimulai dengan pengumpulan data melalui survey kawasan, wawancara dan riset melalui internet sehingga dari pengumpulan data tersebut akan mendapatkan kesimpulan berupa potensi kawasan, ancaman, dan kebutuhan dari kawasan tersebut baik secara fisik maupun dari masyarakatnya sendiri. Setelah mendapatkan kesimpulan dari data dan analisis dilakukan penentuan program dimana penentuan program tersebut dilakukan berdasarkan rekomendasi dari preseden yang ada dan menggunakan teori The Great Good Place oleh Ray Oldernburg sebagai dasar penentuan program. Setelah program ditentukan dilanjutkan dengan proses penentuan tapak, didalam area kecamatan Semanan. 
Metode penentuan program dan desain dari proyek juga menggunakan metode yang dinamakan metode contextualism menurut buku Kari Jormakka (2003). Metode ini memiliki dasar rancangan untuk berusaha merespon dengan lingkungan sekitar, memperhatikan lingkungan dalam penempatan bangunan sehingga didapat komposisi lingkungan yang serasi. Pemilihan metode berikut dengan dasar agar bangunan dapat memenuhi karakter third place yaitu low profile dimana bangunan harus berusaha menyelaraskan dengan sekitar. Pada proyek third place yang akan dibuat, metode diterapkan dengan memasukkan karakterkarakter fisik pada kawasan Semanan, seperti warna, dan bentuk dari karakter bangunan sekitar. Namun, proyek tetap dibuat memiliki karakter tersendiri yang berbeda dari sekitar namun tetap selaras agar proyek tetap menarik dan dapat menjadi magnet bagi pengunjung. Pada program bangunan, metode kontekstual diterapkan dengan membuat program yang mewadahi aktivitas yang biasa dilakukan dan dibutuhkan oleh masyarakat Semanan.

\section{DISKUSI DAN HASIL}

\section{Investigasi Kawasan}

Hasil Survey Kawasan

- Mata Pencaharian Warga Semanan

Mata pencaharian warga kebanyakan sebagai karyawan, dan mata pencaharian kedua yang tertinggi adalah sebagai pelajar yaitu belum bekerja, dan peringkat selanjutnya disusul dengan ibu rumah tangga yang tidak bekerja. Dengan tingginya angka kelompok yang belum bekerja dan tidak bekerja, keseharian warga banyak diisi dengan kegiatan interaksi, bersantai, dan bersosialisasi dengan sesama di teras dan jalan, sehingga warga memerlukan wadah untuk melakukan kegiatan tersebut.

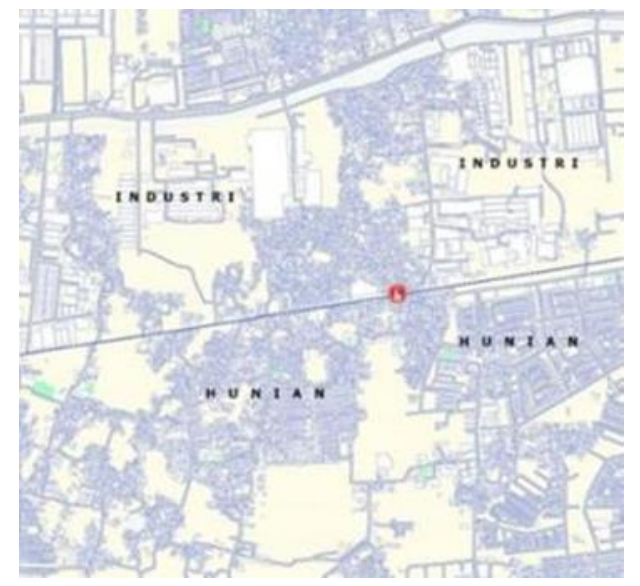

Gambar 1. Peta Semanan

Sumber: cadmapper dimodifikasi/ 2020

\section{- Dominasi area kawasan Semanan dan pengaruhnya}

Dilihat dari peta peruntukkan dan keadaan eksistingnya, kelurahan Semanan didominasi oleh area hunian dan industri, dimana area tersebut dipisahkan oleh Stasiun Kalideres. Dengan banyaknya pabrik dan pergudangan, fenomena ini mempengaruhi sedikit banyak ekonomi, sosial dan budaya dari masyarakat wilayah Semanan. Menurut data BPS Kota Administrasi Jakarta Barat, terdapat 16 perusahaan industri besar, dan terdapat 6 perusahaan industri sedang. Hal yang sangat terasa dari banyaknya kawasan industri adalah munculnya budaya UKM atau Usaha Kecil dan Menengah dari masyarakat, dimana di sepanjang jalan di sekitaran area pabrik, area stasiun dan area yang ramai oleh pengunjung muncul banyak pedagangpedagang baik pedagang keliling, kaki lima, maupun pedagang yang memiliki kios sendiri di dalam rumahnya. Menurut data BPS, penduduk bermata pencaharian sebagai wiraswasta di Semanan berjumlah 7139 , dimana angka ini merupakan angka ketiga terbanyak setelah mata 
pencaharian sebagai karyawan dan yang kedua adalah ibu rumah tangga atau tidak bekerja, yang menandakan bahwa memang budaya UKM warga sangat diminati di kawasan Semanan.

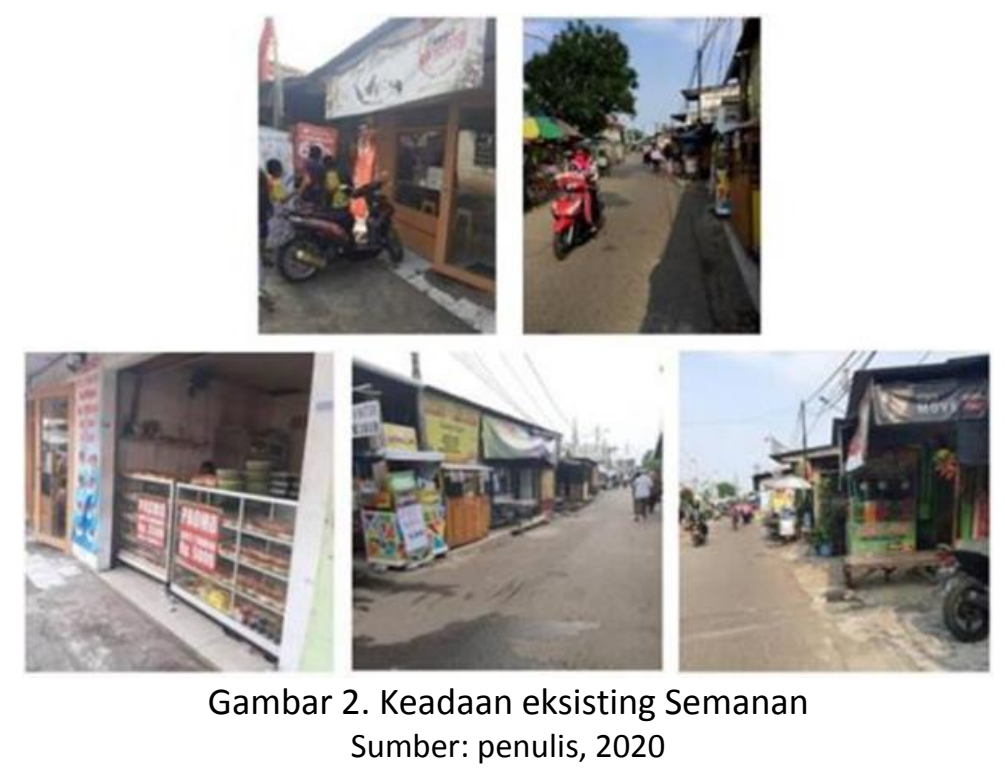

Berikut merupakan gambaran keadaan eksisting Semanan dimana dapat dilihat di gambar 3, di sepanjang jalan dapat ditemui banyak usaha-usaha warga yang dijajakan mulai dari makanan hingga barang lainnnya, dapat dilihat pula di gambar 4, keadaan jalan raya yang padat ketika jam sibuk ditambah dengan adanya sirkulasi dari kereta yang melewati jalan.

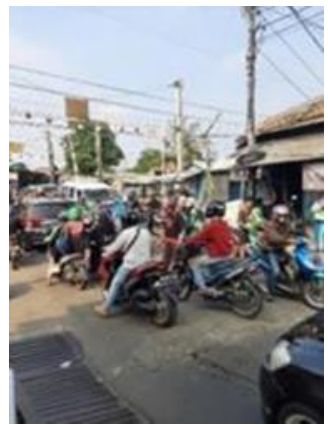

Gambar 3. Keadaan lalu lintas Semanan

Sumber: penulis, 2020

- Petani Semanan

Wilayah Semanan berbeda dengan wilayah Jakarta Barat pada umumnya, wilayah Semanan masih banyak ditemui lahan kosong dan pepohonan. Permukiman yang ada di tempat ini juga tidak terlalu padat, dimana di kawasan ini persawahan juga masih bisa ditemui. Jika dilihat dari data administrasi Jakarta Barat, wilayah kelurahan Semanan memiliki 2 kelompok tani di jenis pertanian tanaman pangan dan 4 kelompok tani di jenis pertanian hortikultura, angka-angka ini menunjukkan bahwa dari seluruh kecamatan Kalideres, kelurahan Semanan memiliki kelompok tani terbanyak. Kawasan persawahan sebenarnya adalah milik perusahaanperusahaan properti dan developer yang belum memiliki rencana untuk pengembangan kawasan sehingga lahan-lahan tersebut, sehingga beberapa tokoh warga setempat kemudian menyewakan lahan tersebut kepada orang yang mau menggarapnya. Dengan fakta bahwa lahan yang digarap bukanlah milik petani itu sendiri, para petani juga memiliki kekawatiran lahan yang digarapnya tidak akan bisa digunakan lagi sebagai mata pencaharian, berdasarkan wawancara dengan para petani dari sumber beritajakarta.id para petani Semanan juga ingin 
mengikuti pelatihan pembinaan kewirausahaan untuk membuat usaha sendiri, maka masyarakat Semanan membutuhkan wadah informal untuk melatih keterampilan mereka.

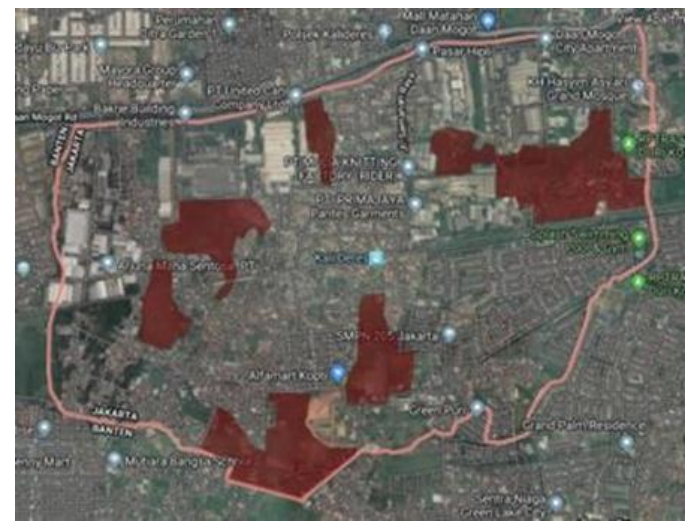

Gambar 4. Peta area sawah Semanan

Sumber: Google Maps dimodifikasi/ 2020

- Minimnya fasilitas publik untuk berinteraksi antar warga

Fenomena selanjutnya yang terlihat adalah minimnya ruang publik dan fasilitas publik yang dapat digunakan sebagai wadah interaksi dan menghilangkan penat warga di kelurahan Semanan, setiap melakukan kegiatan bersama seluruh masyarakat wilayah kelurahan Semanan mengadakan kegiatan tersebut di lapangan kantor kelurahan Semanan, namun hal tersebut tidak sering dilakukan dan lapangan kantor kelurahan Semanan juga tidak dapat digolongkan sebagai third place dan ruang publik warga. RPTRA yang biasanya menjadi titik kumpul warga untuk berinteraksi satu sama lain pun tidak tersedia di kelurahan Semanan, sehingga untuk berkumpul dan sekedar duduk-duduk, berinteraksi dengan warga masyarakat Semanan hanya mengandalkan teras rumah mereka, bahkan anak-anak kecil bermain hanya di jalanan, padahal di wilayah kelurahan Semanan memiliki beberapa sekolah yang rumah-rumah muridnya berada di kelurahan Semanan pula, sehingga ketika libur dan pulang sekolah anakanak membutuhkan wadah yang bisa menampung kegiatan mereka ke arah yang baik. Maka masyarakat Semanan sangat membutuhkan wadah yang dapat berfungsi sebagai ruang bermain anak dan media interaksi warga. Berikut merupakan gambaran dari kondisi eksisting kawasan Semanan dalam melakukan kegiatan interaksi, dapat dilihat karena tidak adanya wadah untuk menampung kegiatan bersosialisasi warga maka warga Semanan memanfaatkan jalan-jalan komplek untuk bermain, duduk santai dan bersosialisasi antar sesama.

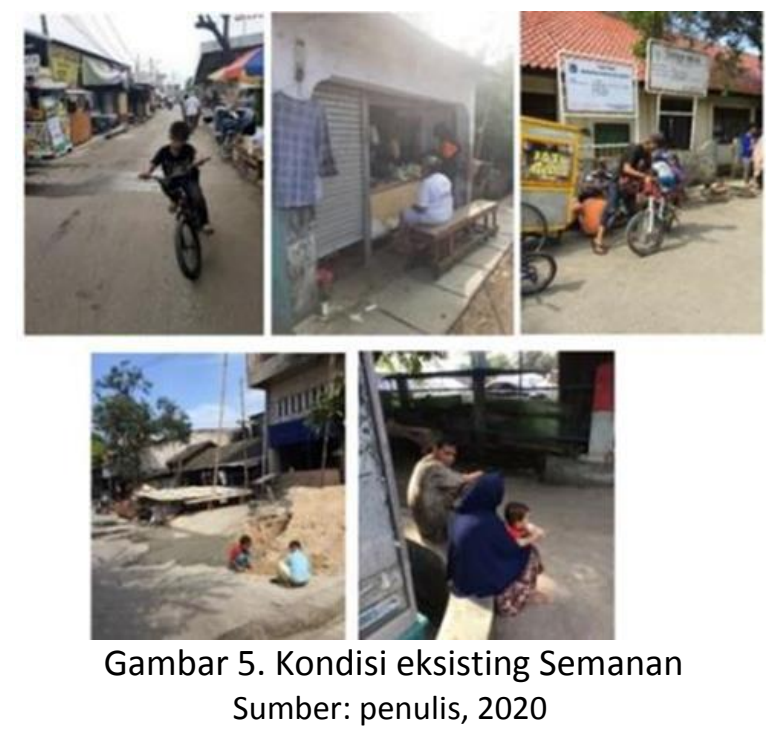




\section{- Kawasan Potensi Semanan}

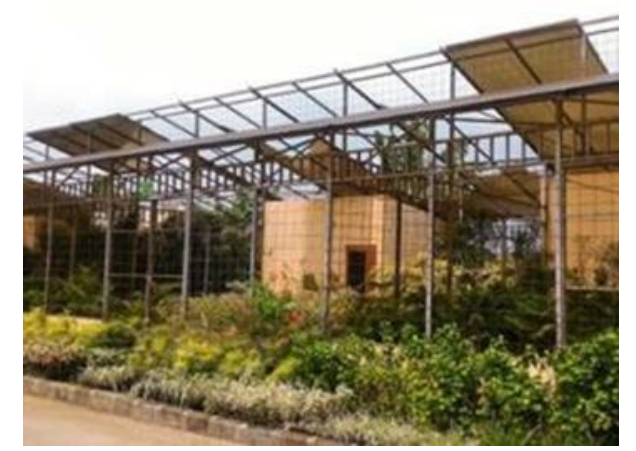

Gambar 6. Sentra Flora Fauna Semanan

Sumber: penulis, 2020
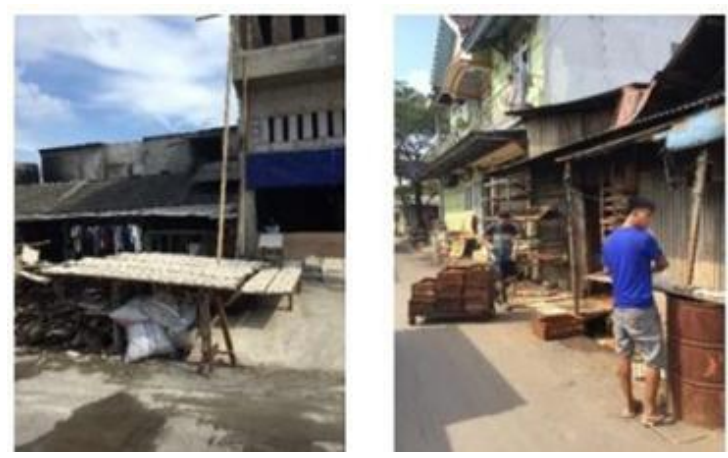

Gambar 7. Perkampungan Tempe Semanan

Sumber: penulis, 2020

Kawasan Semanan memiliki beberapa area yang memiliki potensi dan memiliki karakter sendiri yaitu pertama adalah perkampungan tempe atau warga sering menyebutnya dengan Koperasi Pengusaha Tempe Tahu Indonesia (KOPTI) dimana kampung tersebut sudah berdiri sejak tahun 1992, di kampung tersebut para pekerja membuat tahu dan tempe di Perumahan Industri Kecil (PIK), disana kita bisa melihat bagaimana proses pembuatan tempe dari awal produksi sampai tempe siap diedarkan ke pasaran.

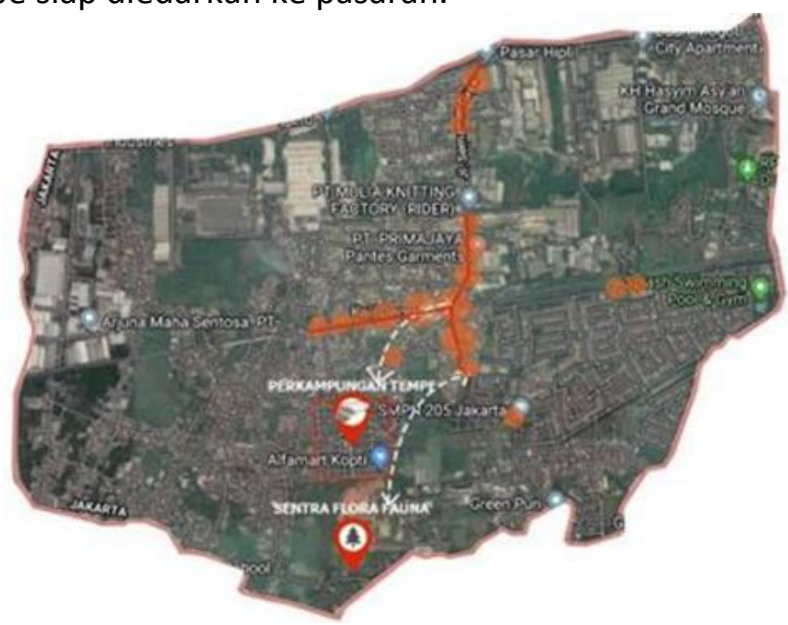

Gambar 8. Area potensi Semanan terhadap pusat keramaian Sumber: google maps dimodifikasi/ 2020

Wilayah potensi kedua adalah Sentra Flora dan Fauna Semanan, keberadaan Sentra Flora dan Fauna Semanan adalah aset pemerintah, dan kepada warga dapat berkunjung kesana entah itu dalam bentuk belajar budidaya ikan atau tanaman. Menjadi pedagang flora dan fauna di 
Semanan menjadi salah satu mata pencaharian masyarakat Semanan, yaitu seperti menjual ikan cupang yang bahkan sekarang diekspor sampai ke Eropa. Wilayah-wilayah tersebut memiliki potensi untuk dikembangkan untuk menunjang kesejahteraan ekonomi dan sosial warga, bahkan pemerintah dan masyarakat sudah mengupayakan wilayah-wilayah ini untuk dikembangkan menjadi area wisata edukasi, namun pengupayaan ini belum berjalan dengan baik sehingga area-area ini belum dikenal secara luas oleh masyarakat di luar Semanan, sebagai contoh pedagang di Sentra Flora dan Fauna mengeluh sepi, jika hal ini terus berlangsung maka mata pencaharian sebagai pedagang di Sentra Flora dan Fauna akan semakin tidak diminati oleh warga. Dengan adanya fenomena-fenomena tersebut warga menginginkan adanya wadah yang dapat membantu perkembangan kawasan potensi Semanan ini, dan membimbing warga untuk pengembangan selanjutnya, sehingga mata pencaharian warga di bidang ini akan semakin berkembang dan semakin memajukan ekonomi dan sosial dari kawasan Semanan.

\section{- $\quad$ Transit Oriented Development}

Kawasan yang mudah dijangkau erat kaitannya dengan transportasi yang memadai, cepat dan efisien. Kelurahan Semanan memiliki moda transportasi utama yang kereta, dimana pusat TOD kawasan Semanan berada di Stasiun Kalideres, yang sekaligus menjadi nodes bagi kawasan Semanan. Dengan pengguna yang tergolong tidak sedikit, dan keramaian yang dapat dikatakan cukup ramai terutama pada jam-jam ramai tertentu, fenomena ini dapat dijadikan sebagai potensi kawasan Semanan.

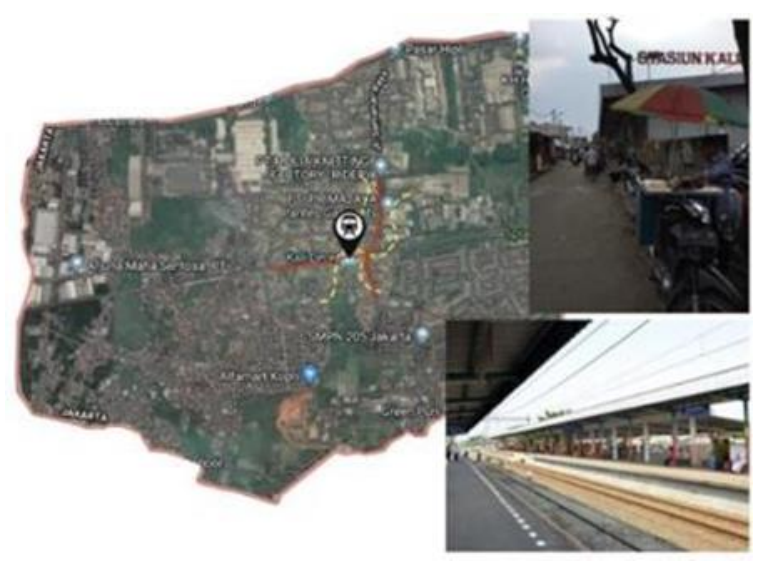

Gambar 1. Stasiun Kalideres

Sumber: google maps dimodifikasi/2020 ; google maps/ 2017

\section{Hasil Wawancara}

Menurut hasil wawancara dengan warga Semanan, dapat disimpulkan bahwa kebanyakan dari mereka merasa kekurangan fasilitas yang menampung kegiatan interaksi publik, maka kebanyakan dari warga menginginkan wadah yang dapat meningkatkan kualitas dan taraf hidup dengan memberikan pelatihan keterampilan dan wawasan lebih. Warga juga menginkan wadah publik yang menjadi tempat pelepasan penat dan bersantai, tempat yang menampung kegiatan komunitas warga dan kebugaran. Maka dari hasil wawancara tersebut dapat dikaitkan dengan fungsi wadah publik yang diinginkan oleh warga, yang nantinya digunakan untuk penentuan program dalam proyek.

\section{Potensi Kawasan}

\section{- Transit Oriented Development}

Dengan adanya kawasan TOD aksesibilitas menuju ke third place yang akan dibuat akan menjadi mudah, pengguna KRL yang akan menuju ke ataupun dari Stasiun Kalideres pun akan dimanfaatkan sebagai potensi terjadinya rembesan alur pejalan kaki di dalam third place. 
- Keinginan warga untuk meningkatkan kualitas kehidupan secara ekonomi dan sosial Proyek third place yang akan dibuat di daerah Semanan harus dapat menjadi area interaksi warga dimana program-program yang dimasukkan dapat meningkatkan kualitas hidup warga baik dari sisi ekonomi dimana dari hasil pengamatan, warga Semanan tertarik untuk membuat usaha sendiri, dan warga yang sudah memiliki usaha sendiri menginginkan adanya perkembangan dalam usaha mereka. Dari segi sosial third place yang dibuat harus dapat mewadahi kegiatan interaksi antar warga dan kegiatan bersantai untuk menghilangkan penat, sehingga kualitas hidup warga diharapkan dapat ditingkatkan di semua umur mulai dari anakanak sampai dengan orangtua dengan adanya third place. Hal ini dapat menjadi potensi bagi program third place untuk membuat suatu program kegiatan yang dapat meningkatkan kreatifitas warga, menghilangkan penat dan menyenangkan sehingga hasil dari kegiatan tersebut akan menghasilkan pemikiran warga yang lebih berkembang sehingga nantinya dapat diterapkan dalam kehidupan berekonomi mereka, dan juga diharapkan dapat menghasilkan kehidupan bersosialisasi warga yang lebih ideal dimana nantinya hal ini akan berujung pada pelepasan penat setiap pengunjung.

\section{Konsep Proyek}

Konsep dari proyek didapatkan melalui hasil analisa tapak kawasan sekitar dan aktivitas, hasil survey terhadap kawasan dan masyarakat Semanan, mendapat kesimpulan berupa wadah yang dibutuhkan kecamatan Semanan yaitu Fasilitas Kegiatan Interaktif Warga Semanan. Dimana wadah ini akan mewadahi aktivitas warga untuk mengembangkan kreatifitas dan keterampilan yang dapat berguna untuk kehidupan ekonomi dan sosial mereka. Program ini juga akan membuat suatu hubungan timbal balik seperti yang diharapkan dalam teori Third Place yaitu tempat untuk berinteraksi dan bersosialisasi antar sesama. Sebagai contoh ketika melaksanakan kelas workshop antar sesama peserta dan pembimbing akan melakukan hubungan interaksi dan pertukaran informasi.

\section{Program Bangunan}

Program bangunan dibuat sesuai dengan kebutuhan warga Semanan, sehingga terbentuklah wadah third place Fasilitas Kegiatan Interaktif Warga Semanan dengan program utama yaitu, Edukasi

Yaitu workshop class yang menampung berbagai kegiatan workshop dengan tema yang menetap yang diambil dari komunitas yang ada di kawasan Semanan seperti workshop tanaman hias dan memasak, dan tema yang bergilir seperti workshop bisnis, kerajinan tangan, memahat dan keahlian lainnya, dan area pendukung berupa perpustakaan dan area pameran yang bertujuan sebagai pelengkap dari program utama sehingga dapat memaksimalkan kerja program dalam proyek.
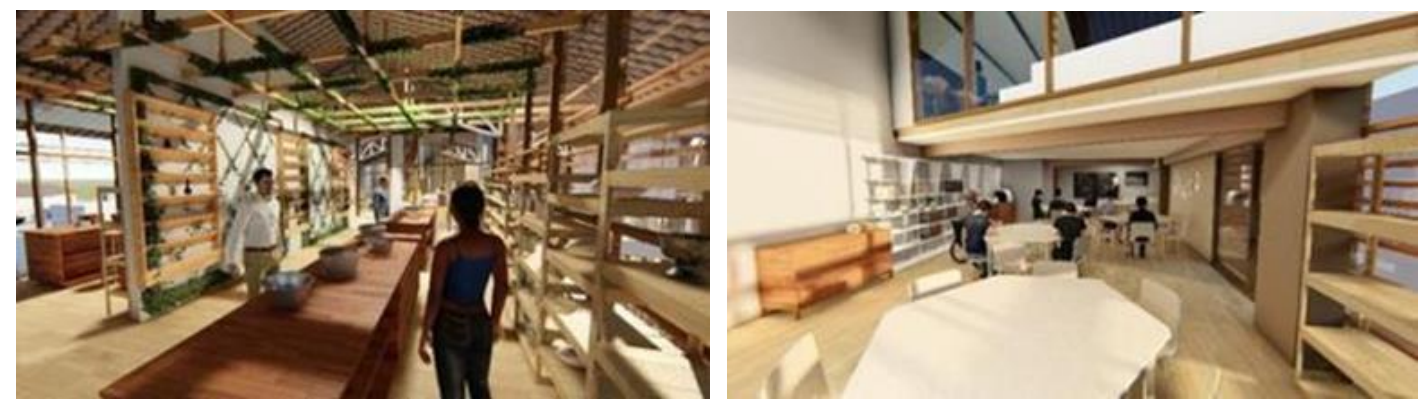

Gambar 10. Ruang Kelas Workshop

Sumber: penulis, 2020 

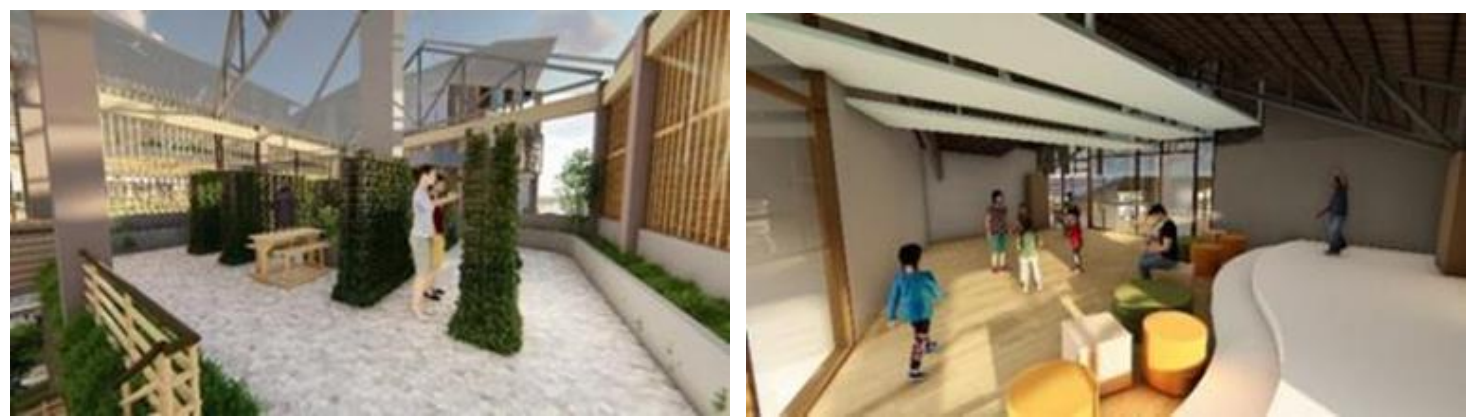

Gambar 11. Area tanaman hias (kiri), Area ruang kegiatan (kanan)

Sumber: penulis, 2020

\section{Entertain}

Food court, play area, taman \& plaza dimana area tersebut dibuat untuk mewujudkan visi bangunan sebagai area berkumpul dan menghilangkan penat, area-area tersebut dirancang menampung kegiatan berkumpul dengan latar tempat dan desain yang menarik.
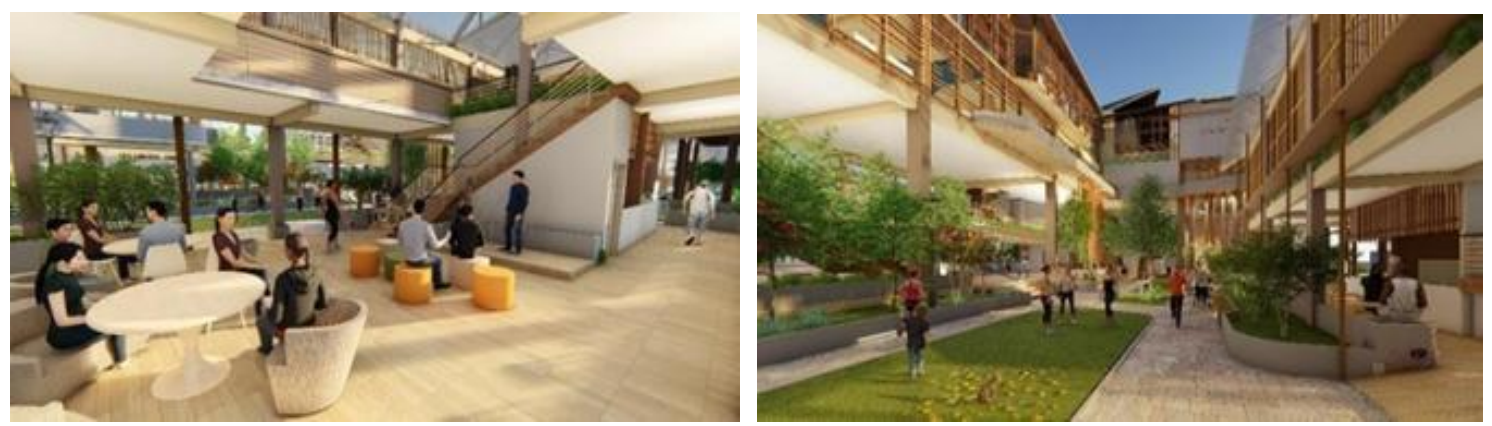

Gambar 12. Area food court live music (kiri), Taman dan plaza (kanan)

Sumber: penulis, 2020

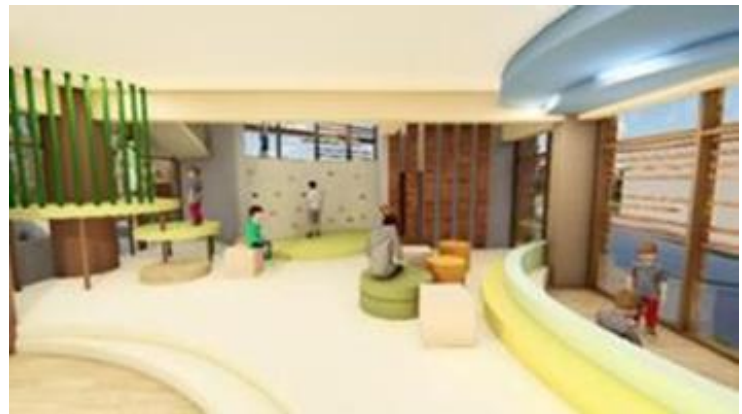

Gambar 13. Play area

Sumber: penulis, 2020

Interaksi

Program ini diwujudkan dengan keseluruhan desain program yang berusaha memaksimalkan kegiatan pertukaran informasi antar sesama pengunjung. Berdasarkan hasil keperluan dan kebutuhan ruang dari program proyek dapat disimpulkan bahwa bangunan terdiri dari 4 lantai utama 1 lantai mezzanine dan 1 lantai basement untuk keperluan service. Dimana KLB dari proyek sebesar $4670 \mathrm{~m} 2$, KDB sebesar $1083 \mathrm{~m} 2$, dan KDH sebesar $878 \mathrm{~m} 2$. Berikut merupakan diagram mengenai luasan dan zoning dari proyek dimana persentase fungsi bangunan terbesar merupakan area workshop sebagai program utama dari proyek. 


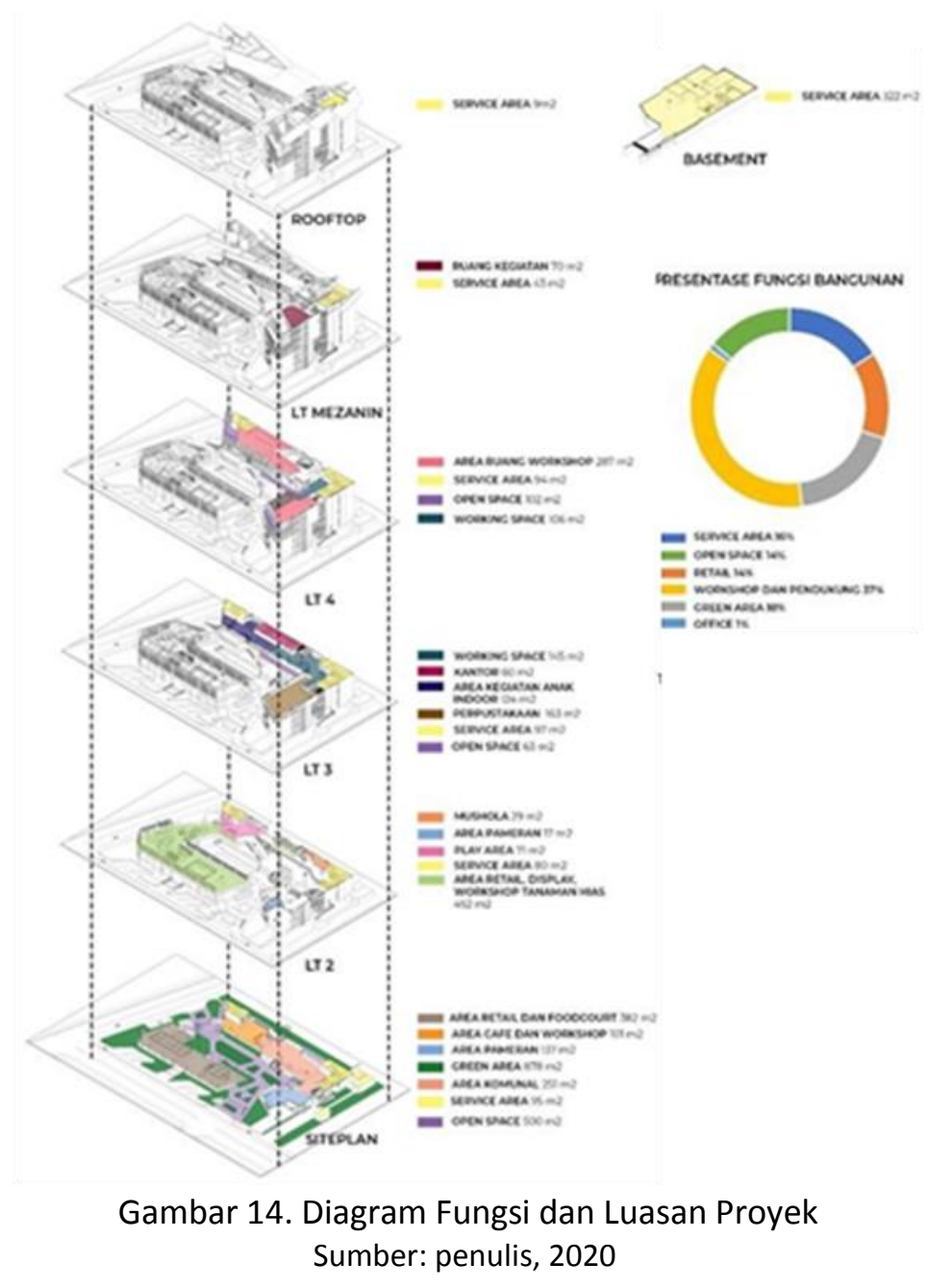

\section{Gubahan Massa dan Zoning Massa}

Konsep desain dari proyek berusaha menjawab kebutuhan dari kawasan Semanan secara fisik dan non fisik. Area publik yang dapat mengundang masuknya pengunjung diletakkan di bagian depan yang paling terlihat. Penentuan area publik semi private diletakkan pada area yang lebih dalam sehingga pengunjung yang memiliki keperluan tertentu akan melewati tempat-tempat lain terlebih dahulu. Untuk meningkatkan rembesan pengunjung dari pejalan kaki, dibuat desain area proyek yang menembus dari satu titik menuju titik lain. Desain juga dibuat merespon keadaan eksisting tapak yang kekurangan area terbuka hijau. Ciri khas kawasan dibuat menonjol dengan aplikasi pada program, dan desain proyek secara fisik, sehingga terciptalah desain proyek yang kontekstual tidak hanya secara fisik juga secara program. Bentuk rancangan dibuat sesuai dengan konsep desain tersebut. Proses gubahan massa dibuat dimulai dari mengikuti bentuk lahan dan dibuat memiliki area sirkulasi yang menembus dari satu titik menuju titik lain sehingga membentuk 2 gubahan terpisah yang berada di area belakang dan area depan, untuk meningkatkan rembesan pejalan kaki. Proses selanjutnya adalah penyesuaian bentuk bangunan sesuai kebutuhan yaitu peninggian bangunan, penyesuain maju mundur bangunan sehingga bangunan tidak akan terlihat massif, setelah itu konektivitas antar massa dihubungkan. Setelah melakukan seluruh proses dibuat lah zoning setiap massa bangunan sesuai dengan konsep desain yaitu peletakkan area publik yang mengundang di area depan dan mudah terlihat, yaitu area retail dan food court dimana area tersebut menampung kegiatan makan dan bertemu pengunjung sehingga akan timbul rasa penasaran oleh pejalan kaki yang melewati area proyek dan terjadilah respon pejalan kaki yang masuk ke dalam area proyek. Area workshop dan pendukungnya diletakkan di area gubahan 
belakang. Zoning area pusat yang menghubungkan seluruh gubahan merupakan area taman \& plaza, area terbuka berupa taman dan plaza dibuat maksimal di dalam bangunan untuk merespon keadaan eksisting Semanan yang minim ruang terbuka hijau. Untuk sirkulasi kendaraan hanya dibuat di area luar dengan tujuan memaksimalkan pergerakan pengunjung di area dalam proyek dan memaksimalkan fungsi taman \& plaza sebagai tempat berkumpul dan beraktivitas.
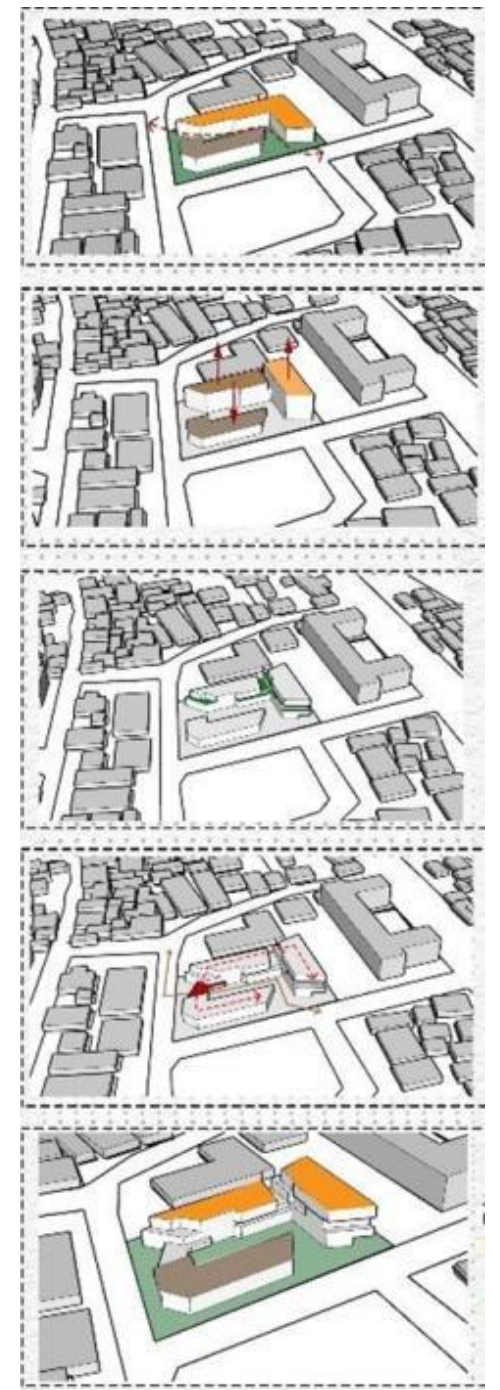

Gambar 15. Gubahan Massa dan Zoning

Sumber: penulis, 2020

\section{KESIMPULAN DAN SARAN}

\section{Kesimpulan}

Berdasarkan hasil analisis mendapat kesimpulan bahwa wadah third place yang dapat menjawab kebutuhan masyarakat Semanan adalah Fasilitas Kegiatan Interaktif Warga Semanan, merupakan ruang yang mewadahi kegiatan interaktif yang dibutuhkan oleh masyarakat Semanan. Kegiatan interaktif yang diwadahi dalam proyek adalah kegiatan yang berusaha melatih kreatifitas dan keterampilan warga sehingga dapat berguna untuk kehidupan ekonomi dan sosial warga. Kegiatan tersebut ditampung dalam kelas workshop dan fasilitas pendukung lainnya seperti perpustakaan, play area dan area tanaman hias yang diadakan di dalam proyek, dalam workshop nantinya hasilnya dapat dipertunjukkan ke masyarakat luas di area pameran, sehingga ada timbal balik yang terjadi. Fasilitas pendukung lainnya seperti perpustakaan, food court, taman \& plaza dibuat untuk mendukung kegiatan bertemu, berkumpul dan berinteraksi yang menjadi hakikat dari wadah third place, area-area 
ini dibuat pula dengan desain dan konsep yang berusaha mendukung interaksi antar sesama pengunjung dan program. Semua program yang disuguhkan di dalam proyek, dengan konsep desain yang berusaha menyesuaikan dengan lingkungan sekitar. Diharapkan dengan adanya wadah third place ini akan bermanfaat untuk peningkatan kualitas hidup warga Semanan baik secara kehidupan ekonomi dan kehidupan berinteraksi bersosialisasi warga.

\section{Saran}

Diharapkan untuk studi lanjutan desain dapat menganalisa kembali kekurangan dari proyek third place sehingga dapat dikoreksi dan diperbaiki kekurangan dari desain. Untuk pembangunan proyek third place kedepannya diharapkan dapat memprioritaskan kebutuhan dari kawasan proyek sehingga nantinya proyek akan berfungsi semaksimal mungkin dalam mengikatkan kualitas hidup masyarakat kawasan.

\section{REFERENSI}

Bosman, C. \& Dolley, J. (2019). Rethinking Third Places. Cheltenham: Edward Elgar.

Florida, R. (2012). The Rise Of The Creative Class . New York: Basic Books.

Gallagher, J. J. (1985). Teaching the Gifted Child . Longman Higher Education.

Jormakka, K. (2008). Design Methods. Birkhauser.

Kurniati, E. \& Rachmawati, Y. (2010). Strategi Pengembangan Kreativitas pada Anak Usia Taman Kanak-Kanak. Jakarta: Kencana.

Oldenburg, R. (1997). The Great, Good Place. Cambridge: Da Capro Press.

Saddoen, A. (2020). Pengertian Kreatif : Bentuk-Bentuk, Ciri beserta Contohnya, TheMoonDoggies, diunduh 20 Februari 2020, https://moondoggiesmusic.com/pengertiankreatif/\#gsc.tab=0

Tristanto, B. (2019). Petani di Semanan Ingin Ikut Progam Pengembangan Kewirausahaan Terpadu, beritajakarta.id, diunduh 20 Februari 2020, http://m.beritajakarta.id/read/67012/petani-di-semanan-ingin-ikut-progampengembangan-kewirausahaan-terpadu

Utami, M. (1995). Dasar-Dasar Pengembangan Kreativitas Anak Berbakat. Jakarta.

Wahyono, E. (2018). Merantau ke Ibu Kota Jadi Petani, news.detik.com, diunduh 16 Februari 2020, https://news.detik.com/x/detail/investigasi/20180202/Merantau-ke-Ibu-Kota-JadiPetani/ah 